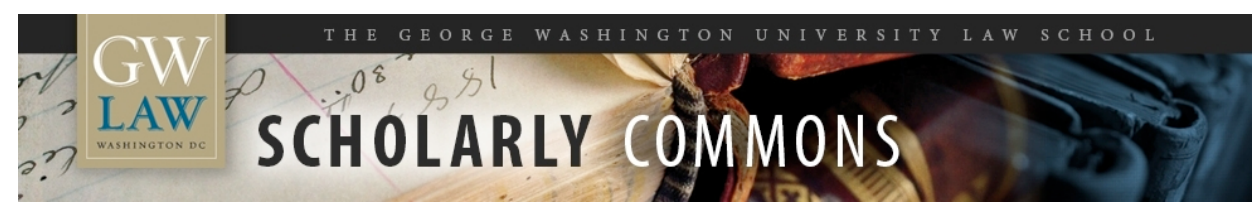

GW Law Faculty Publications \& Other Works

Faculty Scholarship

2001

\title{
The Purposes of Privacy: A Response
}

Jeffrey Rosen

George Washington University Law School, jrosen@law.gwu.edu

Follow this and additional works at: https://scholarship.law.gwu.edu/faculty_publications

Part of the Law Commons

\section{Recommended Citation}

Jeffrey Rosen, The Purposes of Privacy: A Response, 89 Geo. L.J. 2117 (2001).

This Article is brought to you for free and open access by the Faculty Scholarship at Scholarly Commons. It has been accepted for inclusion in GW Law Faculty Publications \& Other Works by an authorized administrator of Scholarly Commons. For more information, please contact spagel@law.gwu.edu. 


\title{
The Purposes of Privacy: A Response
}

\author{
JEFFREY ROSEN ${ }^{*}$
}

I'm honored by the Georgetown Law Journal's sponsorship of this symposium about The Unwanted

Gaze, and by the generosity of the symposium participants, who contributed such provocative essays about the book. Part I one of this response will address the arguments of Professors Post and Lessig about the relationship between privacy and being judged out of context. Part II will address the arguments of Professors Allen, Ehrenreich, and Rubenfeld about the relationship between privacy and gender discrimination. And Part III will address the arguments of Professors Levinson and Strossen about the relationship between privacy and free speech.

I.

"Associate Professor, The George Washington University Law School. I m grateful to Michael F. Williams, Charmaine Yu, Anthony Amarato, and the other editors of the Georgetown Law Journal, for their tireless work in making the Symposium possible; to the Dean and faculty of the George Washington University Law School, for research assistance and invaluable support; and to the Georgetown University Law Center and the Privacy Foundation in Denver, Colorado for generous grants that supported the Symposium. Drafts of this essay were presented at the New School for Social Research and at Rutgers, the State University of New Jersey School of Law, Camden, where the questions and criticisms of the faculty improved it greatly. 
In his generous essay, Robert Post identifies three concepts of privacy in The Unwanted Gaze: the first connects privacy to dignity, the second to autonomy, and the third to the creation of knowledge. He suggests that only the first, privacy as dignity, is distinctively a problem of privacy. The second, he says, is best conceived as a form of liberal freedom from totalizing state surveillance; while the third conception, the problem of misrepresentation or incomplete understanding, should not be understood as a problem of privacy at all ${ }^{1}$, because people can be misrepresented or judged out of context on the basis of public or private information. Lawrence Lessig, too, doubts that the problem of misjudgment is distinctively a problem of privacy. He argues that, in a world of short attention spans, public or private information can be misinterpreted or judged out of context. Privacy, Lessig suggests, is a remedy for a more general failure of the information market; but Lessig suggests that there might be other remedies, such as architecture or social norms. ${ }^{2}$

${ }^{1}$ Robert Post, Three Concepts of Privacy, 89 Geo. L. J., at 1.

${ }^{2}$ Lawrence Lessig, Response to the Unwanted Gaze, 89 GEO. L. J. (2001). 
I'd like to begin by defending the thesis that the problem of being judged out of context is distinctively a problem of privacy. In particular, I want to argue, in response to Post, that when private information is taken out of context, the social judgments that result are, in fact, more damaging to the individual, and more likely to lead to cognitive errors on the part of society, than the social judgments that result when public information is taken out of context. When private information is taken out context, the only way to try to put the information in a broader context is to reveal more private information, which only increases the risk of misinterpretation, because certain kinds of private information can only be understood in a context of intimacy. Certain kinds of private information should only be exposed under conditions of trust, which means that even if the revelation of more private information led to more understanding, it would nevertheless compound the injury of the initial exposure. This injury, I want to argue, is an offense against autonomy as well as dignity, against the self-defined "I" as well as the socially defined "me." The autonomy that the backstage area protects is not merely freedom from totalizing forms of state scrutiny but also from overly intrusive forms of social scrutiny. And respecting the privacy of the backstage spares us from the burden of justifying differences that no one in a pluralistic society should be forced to subject to communal inspection and debate. 
Post says there is no reason to accept the propositions that it is particularly important to individuals to resist misjudgments based upon private information ${ }^{3}$ or that it is particularly hurtful to individuals to be misjudged upon private information. ${ }^{4}$ Let me defend both propositions by thinking, first of all, about misrepresentations on the basis of public information that is taken out of context. This is Post's football player, whom everyone remembers for making a single bone-headed play; or Post's author, who receives an unfair review of a deserving book. It's true, as Post says, that misrepresentation in the public eye is independently distressing whenever it occurs, regardless of whether it is caused by the revelation of 'private' facts. ${ }^{5}$ But if I'm a football player who makes a boneheaded play, I can improve my image by playing better next time. If I'm an author who gets a bad review, I can point to a better one. If I'm a president who gets sick a state dinner, I can have a Gulf War. Of course, if I'm misjudged on the basis of public information, I might also choose to correct the misimpression by revealing private facts the football player might hold a press conference explaining that his wife had just been diagnosed with scurvy, just as Lawrence Lessig put his email in context by revealing his music

\footnotetext{
${ }^{3}$ Post, supra note 1 , at 3 .

${ }^{4} I d$. at 7 .
} 
preferences. But misjudgment on the basis of private information requires the involuntary disclosure of more private information, while misjudgment on the basis of public information is more easily countered by behaving in accordance with my public role.

My success in this rehabilitative effort will depend on my ability to attract the public's continuing attention. In a world of short attention spans, I may be misdefined so vividly by a single, memorable public performance that I won't get another opportunity to correct the misjudgments. (This is a version of the devil's horn effect—bad thoughts driving out good.) ${ }^{6}$ But when the misjudgment is based on public information, the problem of the information market results exclusively from Lessig's attention span problem, and more famous people will generally have more success overcoming it than those who have only fifteen minutes in the sun.

Now let's think about misrepresentation on the basis of private information that has been taken out of context. In this situation, both the injury and the remedy look very different. Despite Post's claim to the contrary, misjudgment on the basis of private information is, in fact, more likely to distort the information market,

\section{${ }^{5} I d$. at 2 .}

${ }^{6}$ See Miguel Angel Mendez, California's New Law on Character Evidence: Evidence Code Section 352 and the Impact of Recent Psychological Studies, 31 UCLA L. REv. 1003, 1047 (1984) (noting tendency to judge character reductionistically, focusing on one or two memorable personality traits rather than examining complexities). 
and to damage the individual concerned, than misjudgment on the basis of public information. In the former case, the cure is worse than the disease, and the misjudgment can only be corrected by the revelation of more private information, which leads to further misunderstanding and further harm to dignity and autonomy. 
Consider the case of Lessig's email. Lessig said he didn't consider the publication of the email itself to be especially invasive, but in order to put his joke in context he—and I—had to reveal the fact that he had been listening to the singer Jill Sobule. But the revelation of this contextual backstage information distorted the information market in new ways. Readers of this symposium now know that Lessig wasn't biased against Microsoft, but they think of him as the kind of person who listens to Jill Sobule. He isn't just that kind of person; he also has a passion for Gregorian chants. And now that I've revealed that my friend Lessig likes to listen to Gregorian chants, perhaps I've misrepresented him further: after all, he isn't just a Jill Sobule person and a plainsong person. The point isn't that Lessig's music preferences themselves are in any way embarrassing; the point is that once the backstage curtain is lifted, Lessig and those who know him can only put the information in context by revealing even more private information. But the world isn't entitled to know about Lessig's music preferences, not merely because the world has no time to understand Lessig in all of his complicated and wondrous dimensions—-this is the attention span problem—-but because Lessig shouldn't have to justify his music preferences to the world. Knowledge, even if it is not true knowledge, must be earned by the slow, reciprocal sharing of personal information, which can lead, in turn, to greater intimacy, understanding, and trust. This is the process that is short-circuited when private information is taken out of context. To understand Lessig's joke properly required more attention than the public was able to give, and more intimacy than the 
public was entitled to demand. In this sense, the problem of being misjudged on the basis of private information is an attention span problem, but it is not only an attention span problem. Filtered or unfiltered, certain private information can only be understood in a context of intimacy. Even if you had full access to my DoubleClick logs, containing granular details of everything that I had read or downloaded over the past year, you shouldn't wouldn't understood me in context. Overwhelmed by information, you would eventually change the channel or click to a more interesting web site. 
It would be possible, of course, to device an architectural solution to this manifestation of the attention span problem, just as Lessig suggests that Justice Scalia has designed an architectural solution to the attention span problem at the Supreme Court. ${ }^{7}$ The Supreme Court allows members of the press to watch oral arguments only if they agree to sit through the arguments from beginning to end, on pain of being physically restrained by armed federal marshals. It would be technologically simple, similarly, to set up a trusted system that could restrict access to my DoubleClick logs to those who agree to spend eight hours a day reading them from beginning to end, and would cut off access for those who breached the agreement.

But it would be outrageous for you to demand a trusted system that would allow you to read my DoubleClick logs from beginning to end because you haven't taken the time to earn my trust. The public has a right to try to understand the oral arguments at the Supreme Court, but it has no right to presume to understand everything that I have ever read, browsed, or downloaded. There are certain aspects of my life that I shouldn't have to justify to strangers or to the state.

\footnotetext{
${ }^{7}$ Lessig, supra note 2, at 1.
} 
When intimate information is taken out of context and exposed to strangers, therefore, we experience an injury to dignity independent from the problem of being misunderstood. Note that it is the forced disclosure of the private information, rather than inherently private character of the information itself, that triggers the injury. We can imagine situations in which people voluntarily divulge private information because they think they will be better understood. Before Lessig's email was exposed, he had been defined in newspapers as the brilliant law clerk, who convinced the Supreme Court to move from mainframe to networked computers. On Larry King, he might have chosen to humanize this techie caricature by revealing his weakness for Jill Sobule and Gregorian chants. Similarly, to rebut the fact that he appears wooden in public, Al Gore ostentatiously kissed his wife and talked lustily about their connubial passion. Some degree of slippage between public and private information is inherent in the public sphere unless we insist implausibly that people can only be defined in the thinnest sense by their public roles and when private information is voluntarily revealed, we don't consider this an invasion of privacy.

By privacy, then, I mean the ability to exercise control over personal information, and by personal information, I mean information over which I reasonably expect to exercise control. The legitimacy of my expectations might vary in different contexts. If I'm a senior at a suburban high school, I may prefer that my 
classmates don't know that I like to download the music of Richard Wagner. If the school monitored my

Internet browsing from home and turned the logs over to the school paper, I could justifiably object that I had been misunderstood because of the attention span problem and victimized by an indignity—because of the breach of my reasonable expectations that my Internet browsing was private. But if one of my classmates saw me waiting in line at the Metropolitan Opera and told the world I was a Wagnerite, there would be embarrassment but not injury to privacy and dignity: I was, after all, caught in plain view. Rather than trying to identify a category of personal information that is inherently private, such as music preferences or email to friends, therefore, it may make more sense to focus on the question of control. It is the involuntary wrenching out of context of personal information that itself constitutes an offense against privacy and causes the related injuries I have described—against understanding, dignity, and autonomy. 
Post suggests that the cognitive harm that results from misrepresentation is generic, and that to the degree that I'm forced to reveal more private information to correct the misrepresentation that results from being judged out of context, the injury that results is exclusively a problem of dignity rather than autonomy. But as I argued in The Unwanted Gaze, there are clearly offenses against autonomy as well. Privacy conceived as a form of dignity, as Post suggests, focuses on the social forms of respect that we owe each other as members of a common community ${ }^{8}$; while privacy as autonomy concerns the individuals' ability to maintain a sphere of immunity from social norms and regulations.

Consider the exposure of information about marital infidelity. Unlike the Gores, who offered up telegenic details of their passion to counteract the impression that the vice president was passionless, the Clintons were forced to justify the integrity of their marriage against their will. To rebut rumors that they were angry at each other, the president and first lady had to have themselves photographed dancing on a beach. To rebut popular sentiment that the appropriate response to adultery is divorce, they were forced to enact a degrading atonement ceremony, in which Mrs. Clinton first expressed anger at her husband and then reluctantly allowed herself to be

\footnotetext{
${ }^{8}$ Post, supra note 1 , at 9 .
} 
won back, in the interest of standing by her man. In fact, these banal rituals of atonement and redemption, may well have contributed to less, rather than more, understanding of the reality of the Clintons' marriage, which, like many marriages, may be too complex to be understood outside a context of intimacy. For all we know, Mrs. Clinton may love her husband blindly; perhaps she wasn't as angry at him at the public thought she should have been. Respecting the privacy of the Clintons' marriage would have protected the public from misunderstanding, because the Clintons' marriage is too complicated to be understood by strangers. But it also would have protected the Clintons from having to justify aspects of their life that no one should be forced to submit to public debate. 
Respecting the privacy of the backstage, therefore, spares individuals from pressure to justify their differences and allows them to arrange their lives in a way that differ from social expectations. Imagine a couple that decides to tolerate extramarital affairs, as the Clintons appear to have done. Shielded by privacy, they can sustain a marriage in the face of adultery. But once the adultery is made a subject of public discussion, the couple will face overwhelming social pressure to divorce, because of the conventional view that divorce is the appropriate response to adultery. In many cases, they may succumb to this pressure, even though both would prefer to remain together. The privacy that protects individuals from being judged out of context, in short, does not merely protect individuals from being misunderstood; it allows them to structure their most intimate relations in ways that differ from social norms. 
Post insists that offenses against autonomy are generally limited to the relationship between the individual and the state. But privacy as autonomy is not always conceived so narrowly. Jeffrey Reiman described the notion of privacy as autonomy as conferring title to one's existence. ${ }^{9}$ By limiting society's access to an individual, Reiman concludes, privacy allows individuals to claim ownership of their thoughts and actions. This conception of privacy seems to me implicated in pervasive surveillance on the Internet. Surveillance by faceless web sites can hardly be conceived as a breach against dignity, since privacy as dignity presupposes some kind of relationship of mutuality. By contrast, pervasive surveillance might inhibit one's thoughts and actions in a way that implicates autonomy, even though it does not involve the state. Right now, pervasive surveillance in cyberspace is in its infancy. I find it invasive to be tracked on line and to be bombarded with targeted ads when I surf. Others find it less invasive; the norm right now is contested. It's possible to imagine a world in which profiling is so pervasive and so widely accepted that people define their selves in relation to their profiles. In such a world, my social expectations of privacy could be breached when DoubleClick sends me an ad that doesn't correspond to my virtual profile. So I could file an intrusion on seclusion suit when I'm emailed an ad for Memoirs of a Geisha, even though my past buying habits suggests that I'm more likely to prefer Tom Clancey.

\footnotetext{
${ }^{9}$ Jeffrey R. Reiman, Privacy, Intimacy, and Personhood, in Philosophical Dimensions of
} Privacy: An ANThology 310 (Ferdinand Davis Shoeman ed., 1982). 
In a world of pervasive surveillance, inaccurate rather than accurate profiling could be considered highly offensive to a reasonable person. But accurate or inaccurate, pervasive profiling would still represent an offense against autonomy to the extent that fear of exposure of my profile might inhibit me from reading controversial web sites, buying odd books, or developing my self in a way that differs from social expectations. As Stanley Benn argues, protecting privacy as autonomy is a way of indicating that an autonomous individual is worthy of the respect that allows her to pursue a private enterprise without being observed, ${ }^{10}$ rather than being objectified like an animal in the zoo.

${ }^{1010}$ Stanley I. Benn, Privacy, Freedom, and Respect for Persons, in PHILOSOPHICAL Dimensions of PRIVACY, supra note Error! Bookmark not defined. at 243. 
Here, then, are the injuries that result from being observed out of context in spaces that should be considered private. To the extent that the observation results from unreasonable state extraction of intimate personal information, the subpoenas that exposed the emails of Lessig and Lewinsky, it is an offense against liberal freedom in the traditional sense of threatening the boundaries between the individual and the state. To the degree that observation results from the betrayal of a friend or former lover, such as Joyce Maynard's tell all memoir about J.D. Sallinger, it represents a breach of confidence; and an offense against socially constructed norms of dignity, much like the indignity that would result if I went to a nude beach with a colleague and she snapped my photograph without permission. At this particular moment, tell-all memoirs are still rare enough that reasonable people don't expect that their lovers, during tender moments, are scribbling notes for a book proposal. If social norms changed and tell all memoirs became more common than they are now, such a betrayal might no longer represent an offense against dignity, but they would still represent an offense against autonomy. If individuals can't form relationships of trust without fear that their confidences will be betrayed, the uncertainty about whether or not their most intimate moments are being recorded for future exposure will make intimacy impossible; and without intimacy, there will be no opportunity to develop the autonomous, innerdirected self that defies social expectations rather than conforming to them. 
The dignitary vision presumes a socially embedded self, much like Goffman's gas station mechanics who define themselves in relation to their fellow workers. ${ }^{11}$ The backstage in Goffman's world is a place from which outsiders are excluded. It allows me to let down my masks, but behind the masks, there is no me independent of us. Privacy as autonomy, by contrast, presumes a self-actualized individual self, defined by its differences rather than its similarities from the relevant community. It is this autonomous self that I had in mind when I talked about the need for individuals to be free from observation by society as well as by the state, in order to be spared the need to justify their differences. This is the self that can't develop its individual subjectivity, and can't form relationships of intimacy, without insulation from the gaze of pervasive surveillance. Defining privacy as freedom from observability, the sociologist Robert Merton argues that privacy is necessary because without it "the pressure to live up to the details of all (and often conflicting) social norms would become literally unbearable; in a complex society, schizophrenic behavior would become the rule rather than the formidable exception it already is." ${ }^{112}$ To be observed out of context in private spaces, on the basis of complete or incomplete information, transforms the self from subject to object; and uncertainty about pervasive surveillance makes the

\footnotetext{
${ }^{11}$ Erving Goffman, The Presentation OF Self In Everyday Life 115 (1959).

${ }^{12}$ R. Merton, Social Theory and Social Structure 429 (1968).
} 
development of the subjective self- impossible. This objectification, then, is one of the injuries that results from being observed out of context not merely an offense against dignity, as Post suggests, or a recipe for social misjudgment, as Lessig suggests, but also an intrinsic injury against the autonomous self.

II.

Let me now address the cluster of responses to my arguments about sexual harassment. In The Unwanted Gaze, I don't propose replacing anti-discrimination law with the privacy tort, as Post and Anita Allen suggest. Instead, I suggest that if the hostile environment test were eliminated, some of the speech and conduct it now includes could be recategorized as discrimination because of ... sex and litigated under an expanded understanding of the text of Title VII. It is discrimination on the basis of sex for employers, managers and co-workers who hold sway over economic fates to repeatedly demean, humiliate, embarrass employees because of their sex through sexual overtures and innuendo, Anita Allen plausibly argues. ${ }^{13}$ If so, plaintiffs could challenge this conduct directly under Title VII, which clearly encompasses any speech or conduct that affects the terms and conditions of employment because of sex, whether or not it involves quid pro quo threats. I am

${ }^{13}$ Anita L. Allen, The Wanted Gaze: Accountability for Privacy Invading Sexual Harassment in the Workplace, 89 GEO. L. J. at 19 (2001). 
not arguing for a truncated title VII regime, ${ }^{14}$ as Allen suggests, but an expanded one.

What about conduct that can't be plausibly characterized as sex discrimination? If the hostile

environment test were eliminated, some of this conduct could be challenged under the privacy torts, in cases where they represent serious enough offenses against widely shared norms of dignity to be highly offensive to a reasonable person. This leaves a category of offensive speech and conduct that is currently regulated by the hostile environment test but would be unregulated if the test were eliminated, because the speech and conduct in question doesn't offend communal norms seriously enough to be actionable as an invasion of privacy or doesn't affect the terms of conditions of employment seriously enough to be actionable as sex discrimination. To explore this category, which may not be very large, I'd like to consider a distinction that was not introduced in the book but that may be helpful in identifying what sort of offenses against civility should and should not be regulated in a pluralistic society. Let's think for a moment about the distinction between offenses against dignity and offenses against honor.

Offenses against honor are associated with vertical, aristocratic societies, while offenses against dignity

$$
{ }^{14} I d .
$$


are associated with horizontal, democratic societies. ${ }^{15}$ Offenses against dignity involve a failure to show people the respect and deference to which they are entitled by virtue of their intrinsic humanity; offenses against honor involve a failure to show people the respect and deference to which they are entitled by virtue of their social status or role. In a fascinating article about civility law in Germany, France, and the United States, James Whitman distinguishes between the interest in reputation and the interest in honor. The interest in reputation, according to Whitman, is an interest in making sure that shameful or discreditable things about us do not become public. The interest in honor is an interest in making sure that other people show us respect, not only in public but also in private. ${ }^{16}$ Whitman argues that societies that punish offenses against honor, such as France and Germany, conceive them as status offenses rooted in old aristocratic dueling codes. In the postwar period, these aristocratic codes were universalized, so that the German law of insult now punishes forms of social disrespect, from giving someone the finger to calling them by the familiar $d u e$ rather than formal sie. But although all Germans are now entitled to the deference once reserved for aristocrats, a similar conception of offenses against honor would be inconceivable in America, because we lack hierarchical traditions of compelling people of low

\footnotetext{
${ }^{15}$ For the distinction between horizontal and vertical societies, see generally LAWRENCE M. FRIEDMAN, THE HORIZONTAL SOCIETY (1999).

${ }^{16}$ James Q. Whitman, Enforcing Civility and Respect: Three Societies, 109 YALE L.J. 1279, 1293
} 
status to show respect to those of higher status.

The connections between the German law of insult and certain strains of sexual harassment law are instructive. The German law of sexual respect embodies a traditional conception of sexual honor: it punishes treating a woman as someone of easy virtue, or placing her on the lowest level of social respect (much as Clinton treated Paula Jones when he conveyed the impression that she was nothing better than white trash.) To be actionable, the conduct of the accused must demonstrate an intentionally demeaning valuation of the woman in question, as opposed to treating her as sexually attractive person of a high social status. ${ }^{17}$ Although American feminists might be uncomfortable with aspects of this definition, the roots of American sexual harassment law reflect a similarly hierarchical and status-based conception of sexual harassment. As Catharine MacKinnon wrote in her landmark book, "practices which express and reinforce the social inequality of women to men are clear cases of sex based discrimination in the inequality approach." ${ }^{\prime 18}$ MacKinnon was concerned not about (2000).

${ }^{17}$ Id. at $1307-09$.

${ }^{18}$ Catharine MacKinnon, SeXual Harassment of Working Women 174 (1978) (emphasis omitted). 
offenses against decency or community morality but about the subordination of women. Like pornography, she argued that sexual harassment constructs the social reality of gender inequality and constituted an assault on the status of women as a group. 
Although MacKinnon would surely deny the connection, aspects of her conception of pornography and harassment look very much like traditional conceptions of offenses against honor, in which the seduction or lewd touching of a wife or daughter or female dependent constituted a blow against the entire family. The suggestion that any unwanted sexual expression can be an instrument of gender subordination, an insult against all women, has echoes of the older honor norms, which were designed to protect women's chastity and modesty. And MacKinnon's notion of male-female relationships as inherently vertical parallels that of the aristocratic, honorbased societies. Although honor codes generally apply only to social equals, notions of female honor were extended to women of all classes in traditional societies. Men were expected to display courage and women modesty and shame, and a failure of either could dishonor the whole community. Of course, MacKinnon and the German honor codes are based on very different conceptions of gender equality and seek very different remedies for conduct that subordinates and conveys a demeaning image of women. MacKinnon sought to use sexual harassment law to eliminate the hierarchy that she saw as inherent in gender relations; German law seeks to universalize hierarchy and elevate all women so they are legally entitled to the honor that used to be reserved for aristocratic women. But in their vertical conception of gender relations and their definition of sexual insult as a status based offense rather than an offense against individual dignity, MacKinnon and the German honor codes 
are similar.

The distinction between offenses against honor and offenses against dignity help us understand why MacKinnon's notions of sexual harassment as a status-based offense have always sat uneasily in the American liberal tradition. For the reasons Whitman identifies, modern American law is ill equipped to punish offenses against honor. Even in vertical societies, offenses honor were traditionally punished socially rather than legally, through duels rather than in court. He who appeals to the laws to get satisfaction for an offense to his honor, wrote Montaigne, dishonors himself. ${ }^{19}$ Similarly, when a disgraced formal naval officer named Lieutenant Robert Randolph insulted President Andrew Jackson by trying to pull his nose, Jackson rejected the interference of the courts in what he considered to be an affair of honor. When Randolph was convicted of the assault after Jackson left office, the former president asked President Van Buren to pardon Randolph, citing the wishes of his mother, who had advised him long ago to indict no man for assault and battery or sue him for slander. ${ }^{20}$

\footnotetext{
${ }^{19}$ Frank Henderson Stewart, Honor 80 (1994).

${ }^{20}$ Kenneth S. Greenberg, Honor \& Slavery 21-22 (1996).
} 
In the twentieth century, American society became more horizontal, and the idea of resorting to law to punish offenses against honor became even more implausible. Legal systems that have come to punish offenses against honor, as Whitman shows, tend to be those that began with a strong sense of hierarchy and aristocratic deference and then universalized these norms. American society, by contrast, has no similar sense of hierarchy, and especially in an age of dissensus, there is no social agreement about what kind of deference different groups are entitled to by virtue of their status.

The sociologist Peter Berger traces the evolution of the self in America, and in modernity more generally, from one rooted in dignity rather than honor. Dignity as against honor always relates to the intrinsic humanity divested of all socially imposed roles or norms, he writes. ${ }^{21}$ The concept of honor implies that identity is essentially, or at least importantly, linked to institutional roles. The modern concept of dignity, by contrast, implies that identity is essentially independent of institutional roles. In the world of dignity, in the modern sense, the social symbols governing the interaction of men is a disguise. The escutcheons hide the true self. It is precisely the naked man, and even more specifically the naked man expressing his sexuality, who represents

\footnotetext{
${ }^{21}$ Peter L. Berger et Al., The Homeless Mind: Modernization And Consciousness 90 (1973).
} 
himself more truthfully. ${ }^{22}$

It is little wonder that honor has no standing in American law, and that insults are only actionable if the offended party can prove material damage. ${ }^{23}$ In a world of pluralization of social worlds, social mobility, and the vast increase in communication among groups speeded by technology, it would be impossible to enforce a rigid sense of self linked to unchanging social roles; and there is too much disagreement about appropriate standards of behavior, and who deserves deference from whom, to codify offenses against honor in any meaningful sense. By contrast, American law is better equipped to adjudicate serious offenses against dignity because dignitary offenses, as Post argues, are rooted in social consensus about deference and demeanor. This is why the torts of intrusion and offensive public disclosure of private facts ask whether the invasion would be highly offensive to a reasonable person. Like the tort of defamation, the invasion of privacy torts describe conduct that results in extreme shame, anger or distress as a resolution of the violation of widely shared social expectations about the respect to which a woman (or man) is entitled as a human being, rather than a representative of a particular gender, profession, or social class.

\footnotetext{
${ }^{22} I d$. at 92 .

${ }^{23} I d$. at 86 .
} 
The vagueness of the hostile environment test, I think, sweeps in a small category of insulting conduct that is offensive, but about which there is no widespread social agreement about whether or not it constitutes a serious offense against dignity or sex equality. Some of the speech and conduct in this category might be described as an offense against honor such as the highly contested notion that dirty jokes told by men in mixed company are inherently degrading to women. While a few people may believe that any sexual speech in the workplace tends to subordinate women (this is the modern vocabulary for an honor-based offense), many others strongly disagree. For the narrow category of speech that might be considered an offense against a woman's honor without rising to the level of offending shared norms of dignity or gender equality, the hostile environment test, which asks what a reasonable person would find hostile or offensive, is too vague to distinguish between speech that should and should not be actionable. Like Catharine MacKinnon's arguments for regulating pornography, from which it is derived, the hostile environment test risks enshrining what Post has called the pluralistic conception that certain groups are entitled to respect by virtue of their group status, inviting the law not only to define and enforce conception of group identity within the area of gender, but also to impose norms of respect and civility between genders. ${ }^{24}$ This seeks to remove from the realm of the contestable the

\footnotetext{
${ }^{24}$ Robert Post, Constitutional Domains: Democracy, Community, Management 116
} 
highly contested question about what sort of lower level breaches of civility should be actionable. The result, in some cases, is the imposition of liability where civility norms are disputed rather than widely shared.

To illustrate the narrow category of speech that might be deregulated if the hostile environment test were eliminated, imagine three overlapping concentric circles. The first represents conduct that can plausibly be viewed as sex discrimination; the second, offenses against dignity, and the third offenses against honor. Everything in the first circle would be actionable; and everything in the second circle that was serious enough to be litigated under the privacy torts would be actionable. The only conduct that would not be actionable would that in the third circle that doesn't overlap with the other two. 
In The Unwanted Gaze, I argue that the law should not turn what Anita Allen nicely calls the wanted gaze on the narrow category of speech in this circle. And, for what it's worth, I doubt that the Jewish tradition from which I took the title of the book would regulate this kind of speech either. Allen reminds us of the nonvoluntarist tradition in Jewish law which held not only that it was wrong to invade others' privacy but also that it was wrong to be an exhibitionist. But she neglects to emphasize that the privacy of people who don't behave in especially immodest or exhibitionistic ways is supposed to be respected, and those who inadvertently violate the privacy of tolerably discreet people are supposed to avert their eyes. This is the tradition of discretion that we seem to have lost and that Allen perhaps under emphasizes. I argued in The Unwanted Gaze that privacy encompasses not just the right to draw your blinds but also the expectation that, up to a certain point, other people won't look even if you happen to leave the blinds open. And, as Jonathan Rauch reminds us, privacy also includes the expectation that those who do look through the open blinds will pretend not to see. ${ }^{25}$ Rauch cites Michael J. Broyde's recent essay about the Jewish tradition in The Responsive Community, Michael J. Broyde, which notes that adultery, Sabbath violations, ritual violations, and other central tenets of the faith were

${ }^{25}$ Jonathan Rauch, The Bradley Lecture, American Enterprise Institute (2000) (unpublished draft, on file with the author.) 
never subject to shunning unless the person engaged in this conduct in a public manner intended to indicate defiance of tradition. ${ }^{26}$ Imagine the case of an adulterer who attempts to conceal his transgression by seeking prostitutes in another town rather than in his own village, as the Talmud recommends for those who are weak enough to succumb to illicit temptation. If a traveling neighbor, there observes him accidentally is an obligation for the neighbor to look the other way, rather than announcing the indiscretion to their mutual acquaintances. There is nothing wanted, in other words, about gazing at people in private spaces who make minimal efforts to protect their own privacy, except in the most egregious cases of self exposure.

Some of the speech and conduct currently forbidden by the hostile environment test falls into this category that Jewish law would have considered immune from the wanted gaze. I am thinking here of private emails or conversations accidentally intercepted by or forwarded to nosy third parties, many of which are punished under the current legal regime. ${ }^{27}$ And not all the examples that Allen gives of exhibitionistic, vulgar and boorish people violating their own privacy strike me as intentional and egregious enough to justify the kind of

${ }^{26} I d$., citing Michael J. Broyde, The Jewish Tradition, The Responsive Community.

${ }^{27}$ See, e.g., Return to Sender, N.Y. TimEs, Dec. 24, 2000, $\$ 4$ at 2. (detailing case of Brad the Cad, a British lawyer who forwarded his girl friend's intimate email to friends and was disciplined by his law firm for violating its email policy). 
social shaming that Jewish law reserved for the worst offenses against decency and honor. Many including the Clinton and Thomas cases might be viewed as unfortunate misunderstandings, where intentions were misconstrued and unwanted advances pressed in ambiguous circumstances. And under these circumstances, according to the non- voluntarist tradition that Allen invokes, failing to be discrete and forcing a private transaction into the public view is a less defensible invasion of privacy than the conduct that led to the initial misunderstanding. 
Furthermore, as Whitman observes, the American laws that impose privacy by restricting nudity, obscenity, and abusive language look "more like a law of decency than a law of civility." ${ }^{28}$ But the offenses against honor that are currently regulated by hostile environment law are not serious enough to be regulated by the American law of decency or obscenity -- if they were, they could plausibly be actionable under the invasion of privacy torts. (As Post reminds us, the torts of invasion of privacy, like the law of obscenity, is "at least as concerned about policing these 'limits of decency' that embody the 'general level of moral judgment of the community' as with redressing the mental distress of particular plaintiffs. $)^{29}$ In light of the inadequacy of the law of decency as a doctrinal framework for regulating offenses against honor, hostile environment law has arisen as an awkward and unsatisfying attempt to regulate breaches of civility, even though American law is ill equipped to regulate breaches of civility for the reason Whitman describes: there is no social consensus about the derelicts that are serious enough to constitute offenses against civility or honor (as opposed to offenses against decency or dignity.) Certainly the Children's On Line Protection Act, which Allen mentions, is little help in this regard: its model of zoning speech in the interest of protecting minors is not one that could be applied to adults; nor can it

${ }^{28}$ Whitman, supra note 6, at 1376.

${ }^{29}$ Post, Constitutional Domains, supra note 4, at 53 (quoting 2 Fowler v. Harper \& Fleming JAMES, THE LAW OF TORTS $§ 162(1956))$. 
be argued that vulgar speech in the workplace has the illicit secondary effects that the Court has invoked, however implausibly, to justify the regulation of public nudity. ${ }^{30}$

Allen is sometimes vague about whether she favors legal or social regulation when she talks about coercing privacy ${ }^{31}$; perhaps, when she refers to enforceable conduct codes designed to minimize sexual harassment and other forms of gender-related misconduct not related to sexuality as such, ${ }^{32}$ she would be satisfied with voluntary conduct codes adopted by employers voluntarily, rather than imposed in an effort to avoid hostile environment liability. I have no objection to conduct codes that are truly voluntary (as opposed to those that are adopted under the threat of legal liability); indeed, I argue in the book that in a pluralistic universe, different employers should be freer than they are now to strike different balances between privacy and social norms: the military and corporate employers that Robert Post has described as being managerial should be able to impose rigorous conduct codes in the interest of promoting dignity and efficiency; universities might choose

${ }^{30}$ See City of Erie v. Pap' s A.M., 529 U.S. 277 (2000) (holding that secondary effects such as debasement of women and men and the promotion of violence and intoxication justify regulation of public nudity).

\footnotetext{
${ }^{31}$ Anita L. Allen, Coercing Privacy, 40 WM. \& MARY L. Rev. 723, 755-57 (1999).

${ }^{32}$ Allen, supra note 3, at 22.
} 
not to restrict speech under any circumstances, and so forth. But this pluralism is something that the hostile environment regime, which coerces privacy under threat of liability, refuses to allow.

I like Rosa Ehrenreich's distinction between privacy and power, just as I liked her earlier distinction between dignitary harms and discriminatory harms. ${ }^{33}$ I agree that it may be helpful to analyze the harms that result from privacy invasions separately from those that result from unequal bargaining power between individuals and corporations, insurance companies, and the state. But I can't agree with Ehrenreich's suggestion that $[w]$ hen we think about issues such as the confidentiality of our medical records and workplace monitoring, what really bothers us, I think or what certainly should bother us may or may not have much to do with 'privacy', conceived of in the dignitary sense, but it has a great deal to do with power." ${ }^{34}$ Workplace monitoring can be a serious offense against dignity and autonomy regardless of whether or not it results in tangible job detriments: uncertainty about whether or not we are being observed inhibits our ability to act freely in private spaces. This is why people object to being spied on without warning regardless of whether they agree with Ehrenreich that the employment at will doctrine is fundamentally unfair and should be replaced with a radical

\footnotetext{
${ }^{33}$ See Rosa Ehrenreich, Dignity and Discrimination: Toward a Pluralistic Understanding of Workplace Harassment, 88 GEO. L.J. 1, 1-2 (1999).

${ }^{34}$ Rosa Ehrenreich, Privacy and Power, 89 Geo. L.J. , at 11 (2001).
} 
overhaul of employment law. ${ }^{35}$ I also can't agree that the problem raised by breaches of the confidentiality of medical records has little to do with privacy and everything to do with the fact that we lack a decent health care system. Few Americans, if the polls are to be believed, agree with Ehrenreich that the true cure for what ails us in the area of medical privacy is guaranteed affordable access to healthcare for all Americans. ${ }^{36}$ The fact is that, in a pluralistic society, many people can agree in the abstract about the importance of privacy, but few people agree that what Ehrenreich candidly calls Marxist discourse provides an appealing response to perceived inequalities in the distribution of power. Perhaps this is why power issues tend to be debated as privacy issues and also why those who embrace Ehrenreich's provocative, but by no means universally accepted, political prescriptions have chosen, for strategic reasons, to cloak their arguments in terms of privacy rather than class conflict.

\footnotetext{
${ }^{35} I d$. at 14 .

${ }^{36} I d$. at 12 .
} 
Jed Rubenfeld, I think makes a real contribution to the privacy debate with his argument that the core legal norm today is the right to be treated as an object ${ }^{37}$ that is, to be treated the same without regard to sex, race, ethnicity, and so forth. The idea that we are subjects in private and objects in public does, as he suggest, put pressure on the private backstage in ways that sometimes spills over embarrassingly into the public:

Rubenfeld is developing his argument in other places, and this is not the time to explore it in detail. But it strikes me that the phenomenon Rubenfeld discusses is a consequence of the expansion of the legal right to equality beyond the narrow and limited sphere of civil rights, which was its nineteenth century core, to include social and political ${ }^{38}$ rights as well. In the nineteenth century, citizens demanded the same private law rights of contract and property; today, they claim a legal right to be treated precisely the same as all other citizens in the workplace, in schools, and in other spaces that used to be considered immune from legal regulation. The consequence of this creation of a legal right to social equality is inveitably to denude the individual of the subjectivities and contingencies that constitute an individual self: to be treated precisely the same, all individuals must be stripped

${ }^{37}$ Jed Rubenfeld, The Right to Be Treated as an Object, 89 GEO. L.J. (2001).

${ }^{38}$ For a discussion of the evolving conception of equal protection, see Michael Klarman, $A n$ Interpretive History of Modern Equal Protection, 90 Mich. L. REv. 213, 229 n.66 (1991) (quoting Plessy v. Ferguson, 163 U.S. 537, 544 (1896)) (discussing original understanding that the Fourteenth Amendment was not intended to "enforce social, as distinguished from political, equality."). 
of their differentiating characteristics. In a sense, this phenomenon, which I have called elsewhere the legalized self, ${ }^{38 a}$ vindicates the prediction of Alexis de Tocqueville, who argued that as traditional sources of authority were undermined by democracy, legislators would pass an increasingly mind-numbing web of laws and regulations, designed to eradicate special privileges and to prevent those in power from favoring some citizens over others. Uniform legislation was the idea that presented itself naturally to men in centuries of equality, de Tocqueville wrote, because as each of them sees himself little different from his neighbors, he hardly understands why the rule that is applicable to one man should not be equally so to all others. The least privileges, therefore, are repugnant to his reason. ${ }^{39}$ de Tocqueville warned that these laws would run the risk of creating an administrative despotism of a different sort, presided over by lawyers and politicians who acted not like tyrants but like schoolmasters. ${ }^{40}$ Looking far into the future, de Tocqueville feared that as individuals increasingly turned to the state to regulate the most minute aspects of social life, personal interactions could be governed by a

${ }^{38 a}$ Jeffrey Rosen,

${ }^{39} 2$ Alexis de Tocqueville, Democracy in America, pt. 4, at 641 (Harvey C. Mansfield and Delba Winthrop eds. 2000) (1841).

${ }^{40} I d$. at $662,664$. 
network of small, complicated, painstaking, uniform rules. ${ }^{41}$ The rules imposed by this immense tutelary power ${ }^{42}$ might be so arcane, he feared, that citizens would eventually stop trying to understand or resist them, and increasingly large aspects of social and political life would be overseen by the American lawyer, the lone interpreter of an occult science, ${ }^{43}$ who would resemble an Egyptian priest.

The creation of a legalized self interjects minute legal regulation into areas of life that used to be regulated by manners and mores. And those who insist that all individuals have a legal right to be treated precisely the same as all other individuals make the same mistake as Catharine MacKinnon, who insists that women are inherently subordinate to men in the social sphere. ${ }^{43 a}$ In fact, the social sphere of manners and mores is a complex and highly contextualized area, in which hierarchies and status are constantly shifting. Remember that there is a local propriety to be observed in all companies; Lord Chesterfield wrote to his son, in his famous letters on manners, and that what is extremely proper in one company, may be, and often is,
${ }^{41} I d$. at 663 .
${ }^{42} I d$.
${ }^{43} 1$ Id. pt. 2, at 255 .
${ }^{43 a}$ Catharine MacKinnon, 
highly improper in another. ${ }^{44}$

Consider, in this regard, the problem of the backstage. The current hostile environment regime, as I argued in The Unwanted Gaze, makes it difficult for employers to preserve spaces for employees to let down their hair, tell dirty jokes, and relieve the pressures of public performance. This reflects a legal presumption that any backstage behavior by men may be experienced by a reasonable women as hostile and discriminatory. But in fact, as Goffman emphasizes, the backstage is highly dependent on context, and it depends on a sense of vertical exclusion -- an us versus them mentality. Goffman's prototypical backstage was the kitchen in the Shetland Island hotel, where local employees, both men and women, behaved more informally than they did in the dining room, in front of guests. Behind the closed doors of the kitchen, the islanders were able to relax, sample the food with their fingers, and define themselves as a group in opposition to their nominal superiors, who were being excluded. ${ }^{45}$ Goffman was writing in an age when British and American societies were more vertical than they are today. In a more horizontal society that has been integrated by gender, the nature of the backstage has changed, and genuinely integrated backstage areas are possible only when the rules about who is

\footnotetext{
${ }^{44}$ LORD CHESTERFIELD S LETTERS 58 (David Roberts ed., 1992).

${ }^{45}$ Erving Goffman, The Presentation of Self in Everyday Life 118 (1959).
} 
being excluded and who is being included are clearly defined. 
A former student of mine, for example, recently described her experience working as a legal assistant in a law firm. Sometimes she worked with other legal assistants and sometimes with young attorneys. Although both groups were composed of men and women, she said that gender differences never seemed apparent among the other legal assistants because, like the Shetland hotel backstage, the status of each legal assistant in relation to each other and to the outside world was clearly defined. The assistants were roughly the same age and shared a common bond of contempt for their superiors and for themselves because they were headed down the same path. Given the bond of identity and exclusion, the assistants were able to joke among themselves and to make fun of their betters in a truly horizontal backstage space. By contrast, when my student worked among the young male attorneys, she writes, I never felt truly comfortable. On the one hand, I was routinely subjected to the boys' talk: endless commentary about the women in the office, the women in their lives and the women who were their clients or opposing counsel. At the same time, they often cast me as the typical fragile women, taking great pains to interrupt the conversation and apologize for their informal male banter that must be too harsh for my female ears. ${ }^{46}$

My student's experience reminds us of the dangers of making overly abstract claims about hierarchies

${ }^{46}$ Jenny Splitter, Looking for Equality in the Male Backstage (unpublished paper) (on file with author). 
either in insisting that all workplaces are inherently vertical, with women always subordinate to men, or insisting that all workplaces are always horizontal, and that all individuals have a legal right to social equality. A liberal and pluralistic society should tolerate a rich variety of social arrangements, leaving individuals free to form different forms of backstage groupings without fear of corporate or state scrutiny. At the same time, prudent employers should be sensitive to the fact that a backstage which includes men and women who are at clearly different stages in the corporate hierarchy may indeed be perceived by women as hostile and discriminatory, especially when men are in the majority.

III. 
Let me close with a few words about the papers of Professor Levinson and Strossen. Sandy Levinson argues convincingly that the press, in describing privacy invasions, often exacerbates them; ${ }^{46 a}$ and Nadine Strossen argues that case-by-case balancing is often appropriate in deciding how to resolve conflicts between privacy and free speech. ${ }^{46 \mathrm{~b}} \mathrm{I}$ 'm sympathetic to balancing when it comes to restricting the state from invading privacy: in the book, for example, I endorse the idea of a statute that might allow judges, grand juries, or magistrates balance the serious of the offense against the intrusiveness of the search (and, perhaps, the importance of the relationship being invaded) in deciding whether or not a particular subpoena violates the Fourth Amendment. ${ }^{47}$ I also suggest that Congress could create a sexual privilege that protects parties and witnesses in harassment cases from having to discuss their consensual sexual history, although the privilege might be overcome in cases involving serious crimes or imminent harm. ${ }^{48}$ In the same vain, I like Levinson's creative proposal of privilege tickets, which focuses on the intimacy of the relationship rather than the sensitivity of the

\footnotetext{
${ }^{46 a}$ See Sanford Levinson, Title, 89 GEO. L.J. (2001).

${ }^{46 \mathrm{~b}}$ See Nadine Strossen, Title, 89 GEO. L.J. (2001).

${ }^{47}$ Jeffrey Rosen, The Unwanted GaZe 37 (2000).

${ }^{48}$ Id. at 155.
} 
information, although I assume that a privilege ticket could be overcome in especially egregious cases. 
But is it appropriate to balance privacy concerns against free speech when it comes to direct restrictions on the media? Strossen reminds us that, far from being always and everywhere in tension, privacy and free speech are sometimes mutually interdependent. ${ }^{48 a}$ In the book, I noted Milan Kundera's description of how the police destroyed an important figure of the Prague Spring by recording his private conversations and broadcasting them as a radio serial. In a totalitarian society without privacy, Kundera reminds us, free speech is impossible, because citizens have to live in fear of constant exposure. ${ }^{49}$ Nevertheless, in America, where the Fourth Amendment and a web of statutes restrict wiretapping and other undercover information gathering by the state, I'm not convinced that additional restrictions on the media would add measurably to the social expectations of privacy that are necessary for free speech to thrive. The Bartnicki case is indeed a hard one, about which people's intuitions can reasonably differ, but I can't entirely agree with Judge Pollak's observation that the First Amendment prohibits improper restraints on the voluntary public expression of ideas, while [t]here is necessarily, and within suitably defined areas, a concomitant freedom not to speak publicly, one 
which serves the same ultimate end as freedom of speech in its affirmative aspect. ${ }^{50}$

${ }^{50}$ Bartnicki v. Vopper, 200 F.3d 109, 136 (1999) (Pollak, J., dissenting) (emphasis added). 
The media invades the freedom not to speak publicly every day -- from the Washington Post's

gratuitous publication of Robert Packwood's diaries to what Levinson describes as my gratuitous publication of excerpts from the transcripts of Webster Hubbell's telephone calls from federal prison. (I, of course, dispute the claim that the publication was gratuitous, since my criticism of Dan Burton for releasing the unedited transcripts could not have been made as effectively without a concrete example; but whether Hubbell himself felt vindicated or invaded by my description is, as Levinson suggests, an open question: in contrast to my discussion of Neal Lattimore, I did not ask Hubbell's permission to discuss his case.) Nevertheless, if I were restricted from publishing excerpts of Hubbell's telephone conversations even if Dan Burton had taped the conversations illegally before giving me the tapes -- or if a radio station were restricted from broadcasting illegally intercepted telephone conversations that it had legally obtained, the restriction, I think, would inhibit far more free speech than it would encourage. The imposition of civil damages on the media is unlikely to deter the initial illegal invasion; ${ }^{51}$ and while publication naturally compounds the injury, as Judge Pollak observed, this is true whenever the press publishes private information, whether or not the initial invasion was illegal. For these reasons, I agree

${ }^{51} I d$. at 125-26 ( The connection between prohibiting third parties from using or disclosing intercepted material and preventing the initial interception is indirect at best."). 
with the ACLU's argument that the media should not be held liable for publishing truthful information -- even if the information was obtained unlawfully -- as long as the media themselves played no role in the illegal interception. The freedom not to speak publicly --- or, more precisely, the freedom not to have embarrassing but truthful private information appear in the newspapers -- is a freedom well rooted in the French tradition, which allows aristocrats to keep their names out of newspapers ${ }^{52}$, or the German tradition, which holds that freedom of the press and freedom of reporting is limited by the right to inviolability of personal honour. ${ }^{53}$ But it is not one that fits comfortably into the American free speech tradition.

The Bartnicki case brings me back to the point with which I began, and that is the dangers of being judged out of context. The case involved a cell phone conversation between Bartnicki, the chief negotiator of a teachers union, and Kane, the union president, about their recent contract negotiations. In the course of the conversation, Kane said: If they're not going to move for three percent, we're gonna have to go to their, their homes ... to blow off their front porches, we'll have to do some work on some of those guys .... Really, uh,

${ }^{52}$ See Jeanne M. Hauch, Protecting Private Facts in France: The Warren \& Brandeis Tort is Alive and Well and Flourishing in Paris, 68 TuL. L. REv. 1219, 1223 (1994).

${ }^{53}$ Ulich Karpen, Freedom of Expression as a Basic Right: A German View, 37 Aм. J. ComP. L. 395 (1989). 
really and truthfully, because this is, you know, this is bad news (undecipherable) ... you don't discuss this in public ... particularly with the press. ${ }^{54}$ By broadcasting this conversation unedited, however, the radio station contributed to less information, not more. Of course Kane wasn't serious when he talked about blowing off the front porches of his opponents: he was engaging in the kind of hyperbole that, as Kundera reminds us, many of us use in private to shock our friends, amuse them with our heretical thoughts, and so forth. Instead of putting the conversation in context, however, Vopper, the host of the radio station, exacerbated the danger of misunderstanding by airing the tape repeatedly on his show for three days, spicing up the broadcast with harsh criticism of the union leaders.

This lamentable performance shouldn't be legally restrained, but there is no reason that it shouldn't be vigorously criticized by the self-styled media watchdogs, such as Brill's Content, which now have a cottage industry of their own. We need to explore non-legal mechanisms for discouraging privacy invasions by the press, and for redressing the dignitary injury of privacy victims, and public censure is an obvious alternative. Simply describing the invasions might have the effect of bringing them to a larger audience, in the way that Levinson decries, but by criticizing the privacy invaders, the articles could also have the effect of reintigrating the

${ }^{54}$ Bartnicki, 200 F.3d at 113. 
victims into the community, restoring the chains of demeanor and deference, and therefore healing the injuries to dignity and personality rather than compounding them. As Post notes, this social reintigration is the purpose of the tort of intrusion, ${ }^{55}$ but the same result can often by achieved with less collateral damage by writers and journalists rather than by lawsuits. That, in any event, is one of the themes of The Unwanted Gaze, and the reason I told the stories of a number of privacy victims by name is because my goal was to champion their cause and to help to redress the dignitary injuries they had suffered.

${ }^{55}$ Post, Constitutional Domains, supra note 4, at 59 ( The privacy tort . . functions not merely to uphold the chain of ceremony, but also, in appropriate cases, to reforge it when it has been fractured. ). 